\title{
CONSPIRACY CULTURE
}

Post-Soviet Paranoia and the Russian

Imagination 



\section{Conspiracy Culture}

Post-Soviet Paranoia and the Russian Imagination

KEITH A. LIVERS

UNIVERSITY OF TORONTO PRESS

Toronto Buffalo London 
(C) University of Toronto Press 2020

Toronto Buffalo London

utorontopress.com

Printed in Canada

ISBN 978-1-4875-0737-4 (cloth) ISBN 978-1-4875-3612-1 (EPUB)

ISBN 978-1-4875-3611-4 (PDF)

\section{Library and Archives Canada Cataloguing in Publication}

Title: Conspiracy culture : post-Soviet paranoia and the Russian imagination/ Keith A. Livers.

Names: Livers, Keith A., 1963-, author.

Description: Includes bibliographical references and index.

Identifiers: Canadiana (print) 20200253549 | Canadiana (ebook) 20200253662 |

ISBN 9781487507374 (cloth) | ISBN 9781487536114 (PDF) |

ISBN 9781487536121 (EPUB)

Subjects: LCSH: Russian fiction - 20th century - History and criticism. |

LCSH: Conspiracies in literature. | LCSH: Paranoia in literature. |

LCSH: Conspiracies in popular culture - Russia (Federation) -

History - 20th century. | LCSH: Paranoia in popular culture -

Russia (Federation) - History - 20th century.

Classification: LCC PG3096.C67 L58 2020 | DDC 891.73/509353 - dc23

University of Toronto Press acknowledges the financial assistance to its publishing program of the Canada Council for the Arts and the Ontario Arts Council, an agency of the Government of Ontario.

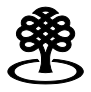

Canada Council for the Arts

Conseil des Arts du Canada

Funded by the Government gouvernement of Canada

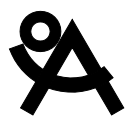

ONTARIO ARTS COUNCIL CONSEIL DES ARTS DE L'ONTARIO

an Ontario government agency
un organisme du gouvernement de l'Ontario 
In memory of my mother, Irene C. Livers (1939-1985) 
